\title{
Guanine nucleotide exchange factor Dock7 mediates HGF-induced glioblastoma cell invasion via Rac activation
}

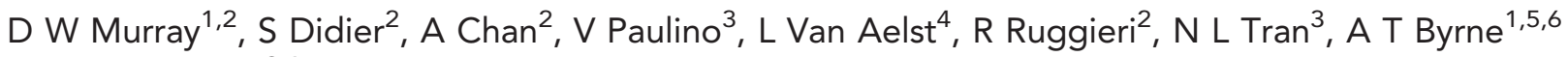 \\ and M Symons ${ }^{\star, 2,6}$
}

${ }^{1}$ Department of Physiology and Medical Physics, Royal College of Surgeons in Ireland, 123 St. Stephens' Green, Dublin 2, Ireland; ${ }^{2}$ Center for Oncology and Cell Biology, The Feinstein Institute for Medical Research, North Shore-Long Island Jewish Health System, 350 Community Drive, Manhasset, NY 11030, USA; ${ }^{3}$ Cancer and Cell Biology Division, Translational Genomics Research Institute, 445 N. Fifth Street, Phoenix, AZ 85004, USA; ${ }^{4}$ Cold Spring Harbor Laboratory, 1 Bungtown Road, Cold Spring Harbor, NY 11724, USA and ${ }^{5}$ UCD School of Biomolecular and Biomedical Science, UCD Conway Institute, University College Dublin, Dublin 4, Ireland

Background: Glioblastoma multiforme (GBM), a highly invasive primary brain tumour, remains an incurable disease. Rho GTPases and their activators, guanine nucleotide exchange factors (GEFs), have central roles in GBM invasion. Anti-angiogenic therapies may stimulate GBM invasion via HGF/c-Met signalling. We aim to identify mediators of HGF-induced GBM invasion that may represent targets in a combination anti-angiogenic/anti-invasion therapeutic paradigm.

Methods: Guanine nucleotide exchange factor expression was measured by microarray analysis and western blotting. Specific depletion of proteins was accomplished using siRNA. Cell invasion was determined using matrigel and brain slice assays. Cell proliferation and survival were monitored using sulforhodamine B and colony formation assays. Guanine nucleotide exchange factor and GTPase activities were determined using specific affinity precipitation assays.

Results: We found that expression of Dock7, a GEF, is elevated in human GBM tissue in comparison with non-neoplastic brain. We showed that Dock7 mediates serum- and HGF-induced glioblastoma cell invasion. We also showed that Dock7 co-immunoprecipitates with c-Met and that this interaction is enhanced upon HGF stimulation in a manner that is dependent on the adaptor protein Gab1. Dock7 and Gab1 also co-immunoprecipitate in an HGF-dependent manner. Furthermore, Gab1 is required for HGF-induced Dock7 and Rac1 activation and glioblastoma cell invasion.

Conclusions: Dock7 mediates HGF-induced GBM invasion. Targeting Dock7 in GBM may inhibit c-MET-mediated invasion in tumours treated with anti-angiogenic regimens.

Glioblastoma multiforme (GBM) is the most common and deadly adult brain malignancy (Kohler et al, 2011). It is an incurable disease with an average life expectancy of 14 months following diagnosis (Van Meir et al, 2010). The morbidity of GBM is primarily due to its rapid growth, angiogenesis and invasion throughout the brain (Furnari et al, 2007; Ricard et al, 2012).
This invasive behaviour precludes total resection of the tumour, leading to rapid recurrence and currently, no anti-invasion therapeutic strategies exist. Moreover, the recently approved antiVEGF therapy using bevacizumab has paradoxically been shown to stimulate the invasive behaviour of GBM (Lucio-Eterovic et al, 2009; Keunen et al, 2011). It is now believed that this occurs,

*Correspondence: Dr M Symons; E-mail: msymons@nshs.edu

${ }^{6}$ Joint senior authorship.

Received 12 July 2013; revised 11 November 2013; accepted 7 January 2014; published online 11 February 2014

(c) 2014 Cancer Research UK. All rights reserved 0007-0920/14 
at least in part, via activation of signalling downstream of the c-Met receptor tyrosine kinase (Lu et al, 2012).

Rho GTPases are key mediators of glioblastoma cell invasion (Fortin et al, 2012; Kwiatkowska et al, 2012; Kwiatkowska and Symons, 2013). These proteins function as molecular switches, cycling between the inactive guanine diphosphate (GDP)-bound and active guanine triphosphate (GTP)-bound states. The exchange of GDP for GTP and thus the activation of Rho GTPases are mediated by guanine nucleotide exchange factors (GEFs) (Bustelo et al, 2007). The activation of GEFs, in turn, often occurs downstream of receptor signalling (Schmidt and Hall, 2002). Once activated, Rho GTPases control cellular processes such as vesicular trafficking, cell polarity, cytoskeletal regulation, and gene transcription (Heasman and Ridley, 2008). Rho GEFs and Rho GTPases have a central role in cell migration and invasion, largely by regulating the actin cytoskeleton and the expression of matrixdegrading proteinases (Sahai and Marshall, 2002; Burridge and Wennerberg, 2004). The Rho GTPase signalling pathway is emerging as a promising target for anti-invasion therapy (van der Meel et al, 2011).

HGF, also known as a scatter factor, signals through receptor activation of c-Met that has been shown to mediate cell migration and growth in embryogenesis; and growth, invasion and metastasis in cancer cells (Birchmeier et al, 2003). HGF is the most potent chemotactic factor known for glioblastoma cells (Brockmann et al, 2003) and interestingly, c-Met, the receptor for HGF localises to invasive pseudopodiae of motile glioma cells (Beckner et al, 2005). Moreover, the expression levels of HGF and its receptor c-Met correlate with astrocytoma grade (Rosen et al, 1996; Koochekpour et al, 1997; Lamszus et al, 1999) and importantly, blocking c-Met signalling, either using ribozymes that target HGF or c-Met, or a c-Met-targeting small molecule, inhibits glioblastoma tumour growth in vivo (Abounader et al, 1999), highlighting the therapeutic relevance of c-Met signalling for glioblastoma. Interestingly, c-Met-mediated signalling has also been shown recently to be important for the maintenance of tumour-initiating stem-like cells in glioblastoma tumours (Rath et al, 2013).

Following c-Met activation, an adaptor protein, Gab1, binds to cytoplasmic tyrosine docking sites on c-Met (Watanabe et al, 2006). A requirement for Gab1 has been shown recently in promotility signalling downstream of c-Met (Chaudhuri et al, 2011). HGF also activates the Rho family GTPases Rac1 and Cdc42 (Royal et al, 2000; Bosse et al, 2007; Palamidessi et al, 2008). The signalling mechanisms that mediate the activation of these GTPases by HGF/c-Met remain to be fully elucidated however (Gherardi et al, 2012).

In this study, we aimed to identify GEFs with enhanced expression in glioblastoma and importance in the context of c-Met-mediated GBM cell invasion. We envisage that identification of the mechanistic role of the key players in GBM cell invasion will lead to a targeted therapeutic approach for the clinical management of GBM especially in combination with an anti-angiogenic (bevacizumab) regimen.

\section{MATERIALS AND METHODS}

Dock7 expression profiling in non-neoplastic brain and human gliomas. Dock7 gene expression was mined in the publicly available NCBI Gene Expression Omnibus data set GSE4290 containing 195 clinically annotated brain tumour specimens. Expression values were filtered and principal component (PC) analysis to investigate the relationship between samples was performed as previously described (Tran et al, 2006). Box plots for Dock7 expression in the respective samples and survival clusters derived from PC analysis were graphed and the significance between the respective populations was tested with a two-sample $t$-test assuming unequal variances as previously described (Tran et al, 2006).

Human tissue specimens for protein analysis. Fresh human astrocytoma (Grades I-IV) and non-malignant brain tissue specimens obtained from epilepsy reduction surgery were collected under a North Shore University Hospital's Institutional Review Board-approved protocol. Tissue specimens were obtained and immediately frozen in liquid nitrogen. Samples were stored at $-80^{\circ} \mathrm{C}$ until further use. Brain tumour tissues were lysed in a buffer containing $50 \mathrm{~mm}$ Tris- $\mathrm{HCl}(\mathrm{pH} 7.5), 2 \mathrm{~mm}$ DTT, $1 \mathrm{~mm}$ EDTA, $150 \mathrm{~mm} \mathrm{NaCl}, 1 \% \mathrm{NP}-40$, supplemented with benzonase (Invitrogen, Grand Island, NY, USA), HALT protease inhibitor cocktail (Thermo, Waltham, MA, USA) and PhosSTOP phosphatase inhibitors (Roche, Madison, WI, USA), on ice with 10-15 strokes aided by a rotor homogeniser. Lysates were decanted by centrifugation at $12000 \mathrm{~g}$ for $15 \mathrm{~min}$ at $4{ }^{\circ} \mathrm{C}$. Fifty micrograms of proteins was tested by western blotting.

Cell culture. The human glioblastoma cell line U87R-GFP (gift from Peter Forsyth, Moffitt Cancer Center, FL, USA) was cultured in Dulbecco's Modified Eagle's Medium (DMEM) F12 supplemented with $10 \%$ fetal bovine serum and $400 \mu \mathrm{g} \mathrm{ml}^{-1} \mathrm{G} 418$ as previously described (Johnston et al, 2007). SNB19 human glioblastoma cell line was obtained from the Cold Spring Harbor Laboratories Tissue Culture Facility (Cold Spring Harbor, NY, USA) and were maintained in DMEM supplemented with $10 \%$ fetal bovine serum. Cells were maintained at $37^{\circ} \mathrm{C}$ and $5 \% \mathrm{CO}_{2}$.

siRNA transfections. siRNA duplexes for target genes were purchased from IDT (Coralville, IA, USA). In all, $3 \times 10^{5}$ cells were seeded in each well of a 6-well cell-culture plate in standard growth medium. After $5 \mathrm{~h}, 2 \mu \mathrm{l}$ dharmafect 1 (Dharmacon, Inc., Lafayette, CO, USA) in $200 \mu \mathrm{l}$ Opti-MEM (Gibco-Life Technologies Corp., Norwalk, CT, USA) was gently mixed with siRNA duplex (at desired nM concentration-see below) in $200 \mu \mathrm{l}$ Opti-MEM. After $20 \mathrm{~min}$, media were removed from cells and this $400 \mu \mathrm{l}$ mixture was added dropwise to cells. In all, $1.6 \mathrm{ml}$ antibioticfree medium was added to each well to a final volume of $2 \mathrm{ml}$ per well. The following day, medium was removed and fresh antibioticcontaining medium was added. On day 3 , the cells were passaged from $2 \times 6$ wells to one $10 \mathrm{~cm}$ dish. The following siRNAs (sense strand provided) were used at $5 \mathrm{~nm}$ : Dock7 duplex \#1 $5^{\prime}$-GAUUAG GUUUGCUUCUGUAGCCAGGUU-3'; Dock7 duplex \#2 5'-GGC AUGAAAUGGGUAGAUAAUCACA-3'; and Gab1 5' ${ }^{\prime}$-CAGAUG UCUUGGAAUACUA-3'. A scrambled non-coding negative control was also used (Catalogue \# DS NC1). (All siRNA primers were obtained from IDT).

Ex vivo brain slice invasion assay. The brain slice invasion assay was performed as described previously (Valster et al, 2005). Animals were maintained and brain slices obtained under a research protocol approved by the Institutional Animal Care and Use Committee of St Joseph's Hospital and Medical Center, Barrow Neurological Institute (Phoenix, AZ, USA). Briefly, $24 \mathrm{~h}$ after transfection, $1 \times 10^{5}$ GFP-labelled SNB19 or U87 cells were deposited in $0.5 \mu \mathrm{l}$ DMEM onto the bilateral putamen of $400 \mu \mathrm{m}$ thick slices of freshly isolated 4- to 6-week-old mouse brain. Serial Z-sections were collected using a LSM 5 Pascal laser-scanning confocal microscope (Zeiss, Thornwood, NY, USA) and the extent of invasion determined as the maximum depth of invasion of the glioblastoma cells.

3D cell invasion assay. Freshly plated cells were incubated in serum-free medium overnight. Basement membrane extract (Trevigen Inc., Gaithersburg, MD, USA) was thawed on ice at $4{ }^{\circ} \mathrm{C}$ overnight. The bottom side of 24 -well transwell inserts was coated with $1 \mathrm{mg} \mathrm{ml}^{-1}$ fibronectin in PBS at $37^{\circ} \mathrm{C}$ for $1 \mathrm{~h}$ and 
washed in sterile PBS and allowed to dry. Cells were trypsinised and counted. In all, $1 \times 10^{5}$ cells were resuspended in $50 \mu \mathrm{l}$ of a mixture of BME diluted to $10 \mu \mathrm{g} \mathrm{ml}^{-1}$ with serum-free media and added carefully to the transwell insert. The BME, containing cells, was allowed to polymerise by incubation at $37^{\circ} \mathrm{C}$ for $30 \mathrm{~min}$. In all, $200 \mu \mathrm{l}$ of serum free medium was added to the upper chamber and $700 \mu \mathrm{l}$ of media supplemented with $20 \%$ serum, or $20 \mathrm{ng} \mathrm{ml}^{-1}$ HGF (Sigma-Aldrich Corp., St Louis, MO, USA) was added to the lower well. Cells were allowed to invade for $24 \mathrm{~h}$ at $37^{\circ} \mathrm{C}$ and $5 \% \mathrm{CO}_{2}$. Following this, chambers were placed in $4 \%$ $(\mathrm{v} / \mathrm{v})$ paraformaldehyde in PBS for $30 \mathrm{~min}$ at room temperature and crystal violet for $40 \mathrm{~min}$ at room temperature. Chambers were washed in distilled water and non-invading cells were removed from the insert with a cotton swab. Inserts were allowed to dry and were imaged using a Zeiss Axiovert 200M microscope (Zeiss) equipped with a $\times 2.5$ objective. Invading cells were counted using the ImageJ software (National Institutes of Health, Bethesda, MD, USA).

Sulforhodamine $\mathbf{B}$ cell proliferation assay. Five thousand cells were added per well of a 96 -well plate in serum free, $10 \%$ serum or $20 \mathrm{ng} \mathrm{ml}^{-1} \mathrm{HGF}$ medium in triplicate. Cells were cultured under standard conditions. The medium was changed every 2 days. Cells were fixed $4 \mathrm{~h}, 3$ days and 5 days after seeding as follows: medium was removed, $100 \mu \mathrm{l} 10 \%$ TCA in PBS was added to each well and left for $60 \mathrm{~min}$ at $4{ }^{\circ} \mathrm{C}$. Each well was washed five times with deionised water and allowed to dry overnight. In all, $100 \mu \mathrm{l}$ of $0.2 \%$ sulforhodamine B (SRB) in 1\% acetic acid was added to each well and the plate put on a plate shaker set to 300 r.p.m. at room temperature for $30 \mathrm{~min}$. Each well was washed five times in 1\% acetic acid and allowed to dry overnight. In all, $200 \mu \mathrm{l}$ of $10 \mathrm{~mm}$ Tris was added to each well and the plate put on a shaker set to 300 r.p.m. at room temperature for $30 \mathrm{~min}$. Absorbance was read at $490 \mathrm{~nm}$.

Colony formation survival assay. Three hundred cells were plated in $6 \mathrm{~cm}$ dishes in triplicate in regular medium. One day after plating, ionising radiation was applied to the dishes using a Gammacell 1000 irradiator $\left({ }^{137} \mathrm{Cs}\right.$; Atomic Energy of Canada, Ltd, Mississauga, ON, Canada). Medium was refreshed every 3 days. Ten days after seeding, cells were fixed by removing medium, washing with PBS and adding 4\% paraformaldehyde in PBS at room temperature for $30 \mathrm{~min}$. Cells were washed with PBS and stained with $0.2 \%$ SRB in $1 \%$ acetic acid with shaking for $30 \mathrm{~min}$. Sulforhodamine B was removed and plates were washed in $1 \%$ acetic acid and allowed to dry. Plates were scanned and colonies were counted using the ImageJ software.

Immunoprecipitation. Following lysis, $400 \mu \mathrm{g}$ total protein was incubated with $2 \mu \mathrm{g}$ c-Met antibody (H-190) (Santa Cruz Biotechnology, Santa Cruz, CA, USA) or $5 \mu \mathrm{g}$ Dock7 antibody (Abcam, Cambridge, MA, USA) adjusted to a final volume of $1 \mathrm{ml}$ with lysis buffer overnight at $4{ }^{\circ} \mathrm{C}$ with gentle rotation. In all, $40 \mu \mathrm{l}$ $50 \%$ slurry of protein A beads was washed five times by centrifugation at $2500 \mathrm{~g}$ for $5 \mathrm{~min}$ and resuspending in $100 \mu \mathrm{llysis}$ buffer. Lysates were added to the beads and incubated by rotating for $4 \mathrm{~h}$ at $4{ }^{\circ} \mathrm{C}$. Beads were collected by centrifugation at $2500 \mathrm{~g}$ for $5 \mathrm{~min}$, supernatant was discarded and beads were washed as above. Protein was eluted by incubation with $30 \mu \mathrm{l} 2 \times$ BME-containing gel loading buffer at $90^{\circ} \mathrm{C}$ for $10 \mathrm{~min}$ and analysed by western immunoblotting as described below.

Western immunoblot analysis. Following treatment, cells were placed on ice, media were removed and washed with ice-cold PBS. PBS was removed and cells were lysed with RIPA buffer (Cell Signaling Technology, Inc., Danvers, MA, USA) containing HALT and PhosSTOP protease and phosphatase inhibitor cocktails. Total protein concentration was determined via Bradford assay and equal amounts of protein were separated by SDS-PAGE. Following transfer onto PVDF membrane, specific proteins were detected using the antibodies below. Dock7, as previously described (Watabe-Uchida et al, 2006), c-Met (c-12; Santa Cruz), Gab1 (Cell Signaling Technology, Inc.), GST (GE Healthcare, Piscataway, NJ, USA). Membranes were developed by ECL. Films were scanned and bands quantified by densitometry using the ImageJ software.

Analysis of Dock7 activity. Following treatment, cells were lysed and activated Dock7 was immediately precipitated by incubation with freshly prepared GST-Rac1-G15A fusion protein, as recently described (Guilluy et al, 2011). Briefly, following incubation, and therefore binding of the fusion protein to active GEFs, the GST protein was pulled down using glutathione sepharose beads and proteins were eluted by boiling in gel loading buffer for $10 \mathrm{~min}$ at $90^{\circ} \mathrm{C}$. Levels of activated Dock7 were then determined by western blotting.

GTPase activation assay. Following treatment, cells were lysed on ice and active GTP-bound Rac was measured in total cell lysates using the G-Lisa assay (Cytoskeleton Inc., Denver, CO, USA) following the manufacturer's instructions. Active Cdc42 levels were determined using the Active Cdc42 Pull-Down and Detection Kit (Pierce-Thermo Fisher Scientific, Waltham, MA, USA).

Quantification of lamellipodia. Cells plated on laminin-covered coverslips (Becton Dickinson, Franklin Lakes, NJ, USA) were serum starved for $16 \mathrm{~h}$ and were then incubated with serum-free DMEM (control) or stimulated for 4 min with serum-free DMEM containing $20 \mathrm{ng} \mathrm{ml}^{-1} \mathrm{HGF}$. Cells were fixed with $4 \%$ formaldehyde in PBS, permeabilised with $0.1 \%$ Triton X-100 in PBS and incubated with Rhodamine-conjugated phalloidin (Molecular Probes-Life Technologies Corp., Norwalk, CT, USA) to stain F-actin. Nuclei were stained with DAPI. Images were acquired using a Zeiss Axiovert 200M microscope. For each experimental condition, images were taken in a random manner. Lamellipodia were traced using the ImageJ software. For each cell, the fraction of the cell perimeter that displays lamellipodia was calculated.

Statistics. All analyses were performed in triplicate. Data are expressed as means with error bars representing standard error of the mean (s.e.m.). Data were analysed using Microsoft Excel. A Student's $t$-test was performed to assess statistical significance with $P<0.05$ deemed to be significant.

\section{RESULTS}

Dock7 expression is increased in high-grade glioma. To discover Rho GEFs of clinical and functional importance in GBM, similar to previous studies (Salhia et al, 2008; Seol et al, 2009), we focused on GEFs that display enhanced expression in GBM tumour tissue vs non-neoplastic brain tissue and with expression that correlates with disease severity. Using a publicly available data set (NCBI, Gene Expression Omnibus GSE4290), we found that Dock7 mRNA levels are increased about two-fold in high-grade astrocytoma in comparison with non-neoplastic brain tissue (Figure 1A). We also examined Dock7 protein expression levels in lysates of tumour and non-neoplastic tissue from independent samples and confirmed increased expression in high-grade glioma tissue $v s$ non-neoplastic brain tissue, with a trend towards intermediate expression levels in low-grade tissue (Figure 1B).

We also compared mRNA expression levels of Dock7 in GBM tumours from patients with short-term survival (median $=401$ days) and long-term survival (median $=952$ days), stratified from the GSE4290 data set as previously described (Tran et al, 2006), and found significantly higher Dock7 expression levels in tumours from patients with shorter survival (Figure 1C).

Dock7 expression is required for human glioblastoma tumour cell invasion. To examine the role of Dock7 in the malignant 


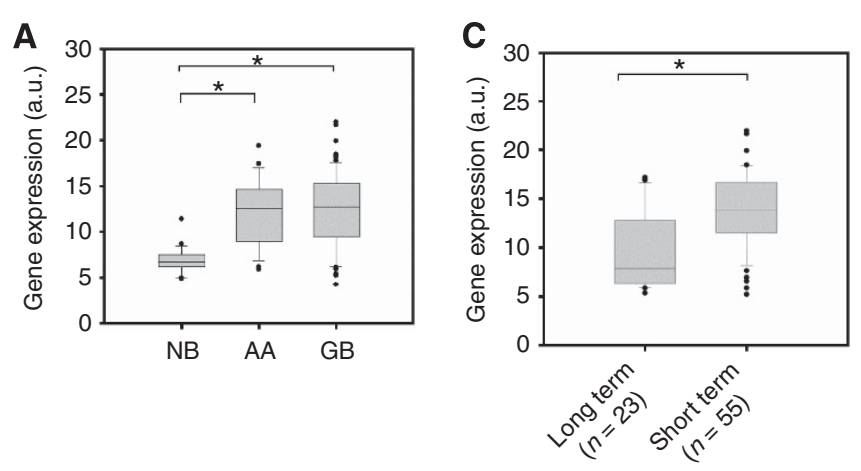

B
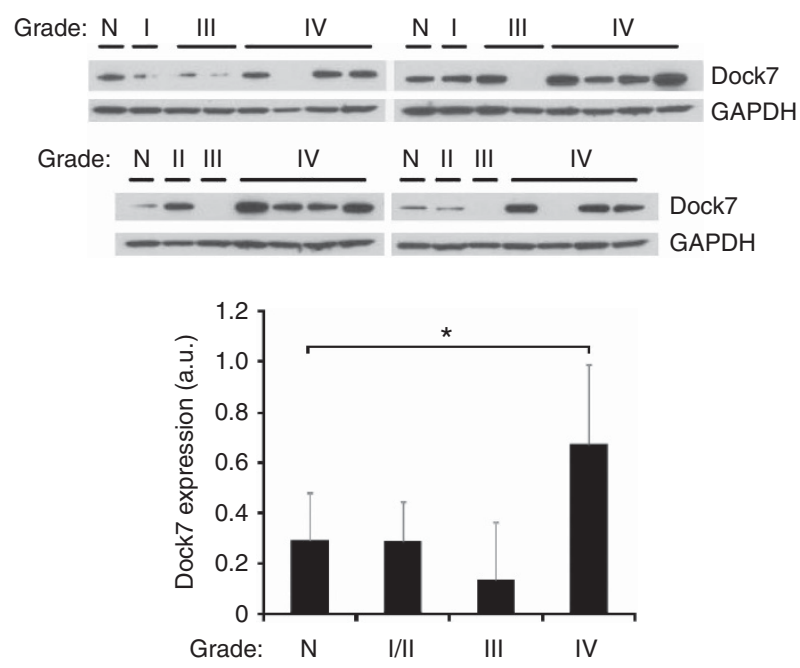

Figure 1. Dock7 expression is elevated in glioblastoma tumours. (A) Box and whisker plots of Dock7 mRNA expression levels from NCBI Gene Expression Omnibus GSE4290 for non-neoplastic brain (NB), anaplastic astrocytoma (AA) and glioblastoma (GB). (B) Western blot analysis showing Dock7 protein expression in non-neoplastic brain (N) and astrocytoma tissue (WHO Grades I-IV). Dock7 expression was normalised by GAPDH expression and was plotted (lower panel).

(C) Principal component analysis of brain tumours from NCBI Gene Expression Omnibus GSE4290 relating Dock7 expression level in longterm (median $=952$ days) and short-term (median $=401$ days) survival groups. Significance between groups was tested with a two-sample $t$-test assuming unequal variances, ${ }^{\star} P<0.01$.

behaviour of glioblastoma, we first investigated the effect of Dock7 depletion on cell invasion. Using an organotypic mouse brain slice ex vivo invasion assay, we found that both SNB19 and U87 GBM cells, using two independent siRNA oligos to minimise the risk of RNA off-target effects, displayed strongly reduced cell invasion (Figure 2A and B).

As mentioned in the Introduction, HGF is the most potent chemoattractant known for glioblastoma cells (Brockmann et al, 2003) and we therefore also examined the effect of Dock7 depletion on HGF-stimulated glioblastoma cell invasion using a threedimensional Matrigel invasion assay. Also in these conditions, depletion of Dock7 potently inhibited glioblastoma cell invasion, both in U87R cells that have been selected for high invasiveness in vivo (Johnston et al, 2007) (Figure 2C) and in SNB 19 cells (Figure 2D). Thus, these data support an important role for Dock7 in HGF-stimulated glioblastoma cell invasion.

Dock7 does not mediate GBM tumour cell proliferation, survival or radio-resistance. We next assessed whether Dock7 also has a role in other aspects of the malignant behaviour of glioblastoma cells. To determine the role of Dock7 in glioblastoma
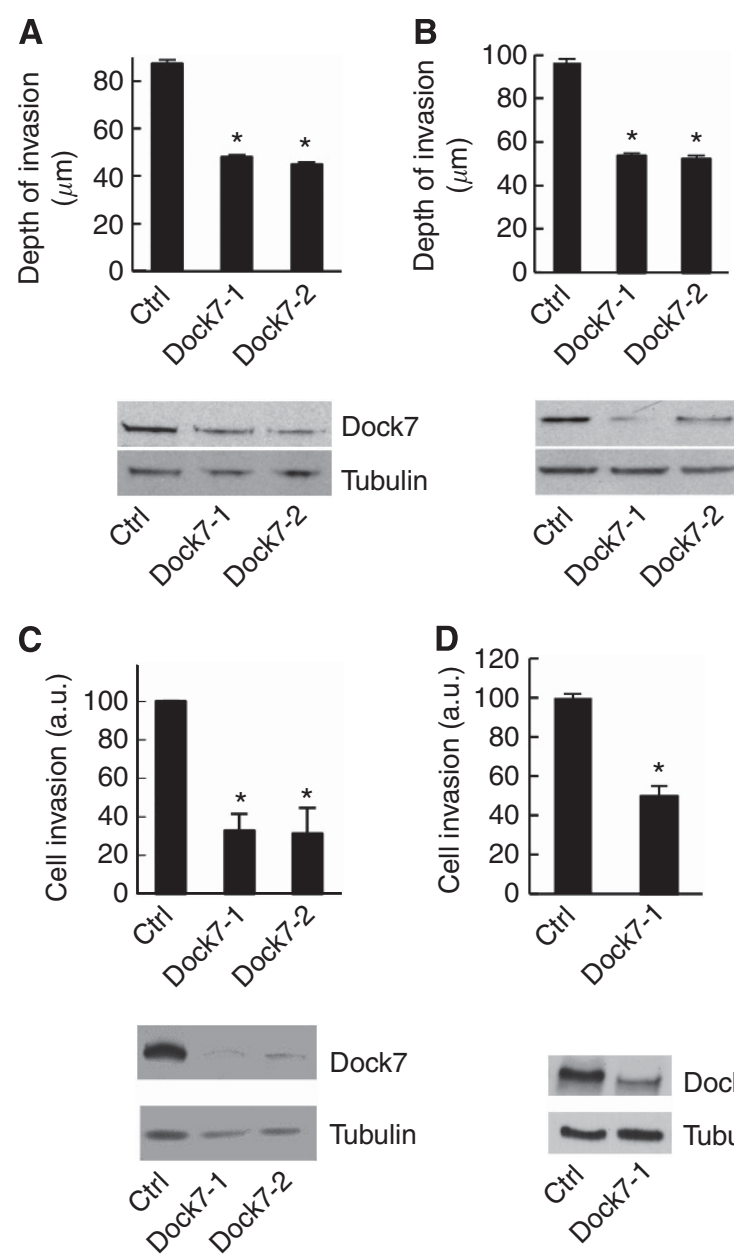

Figure 2. Dock7 depletion inhibits glioblastoma cell invasion. The effect of Dock7 knockdown using two siRNA duplexes (Dock7-1 and Dock7-2) on glioblastoma cell invasion into an ex vivo brain tissue slice using (A) U87 and (B) SNB19 cells. A scrambled non-coding negative control (Cat\# DS NC1; IDT) was used as a control (ctrl). (C) The effect of Dock7 knockdown on U87 cell invasion towards $20 \mathrm{ng} \mathrm{ml}^{-1}$ HGF. (D) The effect of Dock7 knockdown (Dock7-1 siRNA) on SNB19 cell invasion towards HGF. Dock7 knockdown is displayed for each separate cell line under study. ${ }^{\star} P<0.05$, two-tailed $t$-test.

cell growth, we examined the effect of Dock7 depletion using the SRB colorimetric assay, both in serum-containing and serum-free medium and in serum-free medium supplemented with $20 \mathrm{ng} \mathrm{ml}^{-1}$ HGF. We found that depletion of Dock7 did not significantly alter U87R cell proliferation in any of these conditions (Figure 3A-C).

To test for a potential role of Dock7 in glioblastoma cell survival, we used a clonogenicity assay. Knockdown of Dock7 did not cause a significant decrease in colony formation in comparison with control cells however (Figure 3D). We also used this assay to determine whether Dock7 contributes to the resistance of glioblastoma cells to ionising radiation (IR), but we did not observe a significant increase in the sensitivity of the cells to radiation. Thus, taken together, these data indicate that Dock7 does not contribute to the proliferative and survival properties of glioblastoma cells.

Dock7 is required for HGF-induced Racl activation. Dock7 has been shown to possess GEF activity towards Rac1 and Cdc42 (Watabe-Uchida et al, 2006; Yamauchi et al, 2008; Zhou et al, 2013). As we found that Dock7 is required for HGF-stimulated 

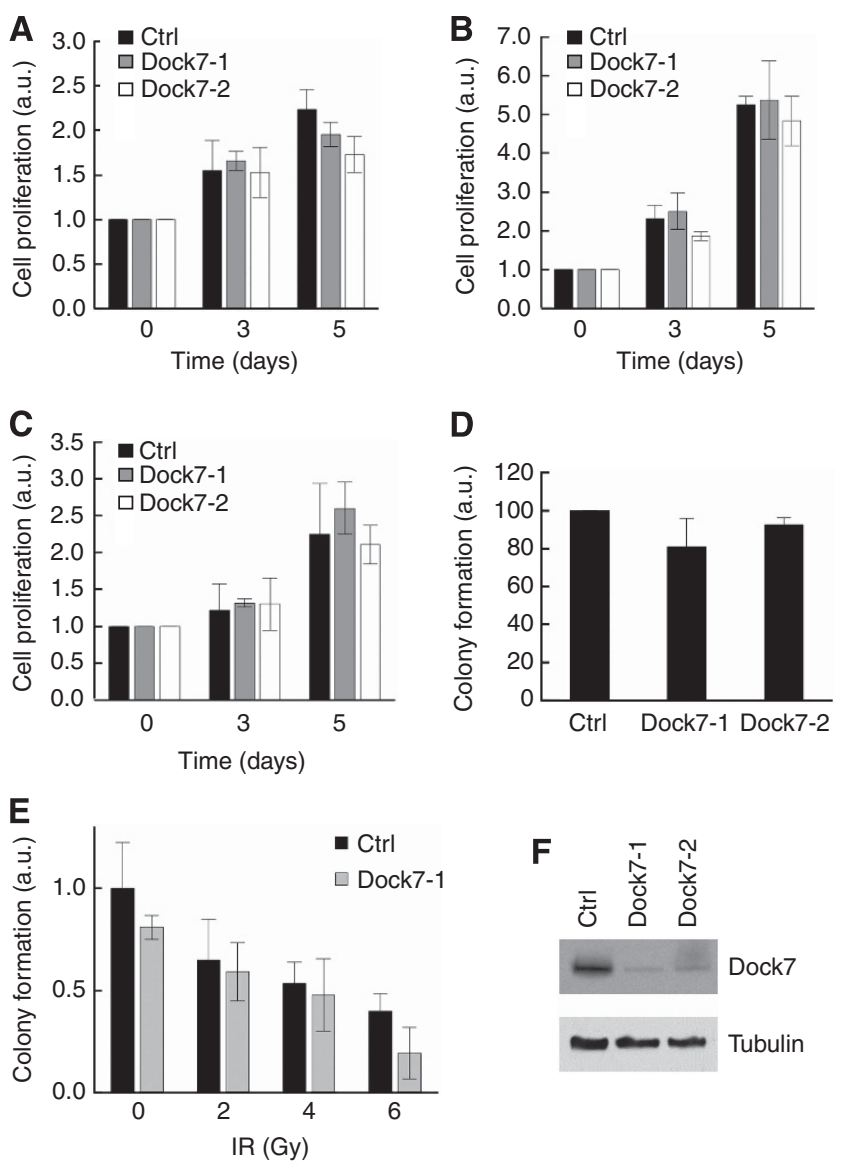

Figure 3. Dock7 is not required for glioblastoma cell proliferation, survival or radio-resistance. The effect of Dock7 knockdown using two siRNA duplexes (Dock7-1 and Dock7-2) on U87R cell proliferation as measured by sulforhodamine $B$ assay in (A) serum-free conditions or (B) $10 \%$ serum or (C) $20 \mathrm{ng} \mathrm{ml}^{-1}$ HGF over a 5-day period.

Normalisation was performed by assigning a value of 1 to day zero readings and expressing all other readings relative to it. (D) The effect of Dock7 knockdown on SNB19 cell survival using a colony formation assay. Normalisation was performed by assigning the reading for control cells a value of $100 \%$ and expressing all other readings relative to it. (E) The effect of Dock7 knockdown on radiation-induced cell death. Normalisation was performed by assigning the reading for nonirradiated control cells a value of 1 and expressing all other readings relative to it. (F) Confirmation of Dock7 knockdown in U87R cells.

glioblastoma cell invasion, we next investigated whether Dock7 is necessary for the activation of these GTPases by HGF. Rac1 activation was quantified using an ELISA that measures the amount of Rac protein in cell lysates through binding to an immobilised Rac effector (Azim et al, 2000). Rac1 is the major Rac isoform expressed in glioma cells and therefore this assay essentially reports on the activation state of Racl (Chan et al, 2005). We found that Dock7 depletion strongly inhibits HGFstimulated Racl activation in U87R cells, at all time points measured (Figure 4A).

To examine whether Dock7 acts on Cdc42 in U87R cells, we used a commercially available pull-down assay that measures activated Cdc42 (see Materials and Methods). However, we failed to detect any HGF-induced Cdc42 activation, even though in the same cells, both EGF and bradykinin resulted in robust Cdc42 activation (Figure 4B) (Kozma et al, 1995).

Rac1 is a key signalling element that controls the formation of lamellipodia, actin-rich protrusions at the leading edge of migrating cells (Ridley et al, 1992). We therefore also determined
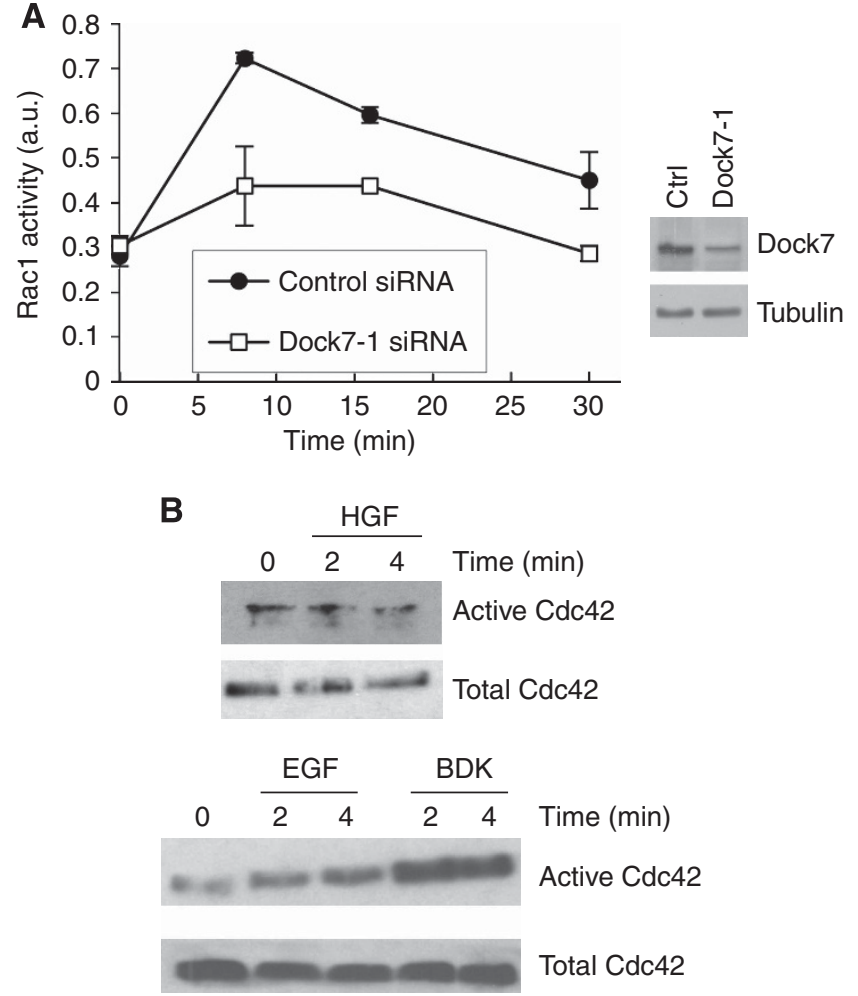

Figure 4. Dock7 is required for HGF-induced activation of Rac1 in human U87R cells. (A) Kinetics of the effect of Dock7 knockdown using the duplex Dock7-1 (right panel; confirmation of knockdown) on HGF-induced Rac1 activation. (B) HGF $\left(20 \mathrm{ng} \mathrm{ml}^{-1}\right)$ does not activate Cdc42 in U87R cells. Both bradykinin (BDK, $1 \mu \mathrm{M})$ and EGF $\left(50 \mathrm{ng} \mathrm{m}^{-1}\right)$ activate $\mathrm{Cdc} 42$ in U87R cells.

whether Dock7 mediates HGF-induced lamellipodia formation. We observed that depletion of Dock7 significantly, albeit not completely, decreased HGF-induced lamellipodia formation (Figure 5A and B). HGF is also known to stimulate cell spreading (Matsumoto et al, 1994). We found that, in contrast to the partial inhibition of lamellipodia formation caused by Dock7 knockdown, depletion of Dock7 abolished HGF-induced cell spreading, measured $60 \mathrm{~min}$ after $\mathrm{HGF}$ treatment (Figure 5A and C), indicating a critical role for Dock7 in this function.

Dock7 binds HGF-activated c-Met via the Gab1 scaffold protein. To further dissect the Dock7-mediated signalling mechanisms that control HGF-induced invasion, we first asked whether Dock7 interacts with c-Met. We readily detected Dock7 in c-Met, but not in control immunoprecipitates (Figure 6A). In addition, we found increased interaction of Dock7 with c-Met upon stimulation of the receptor with HGF (Figure 6A). We also examined whether Dock7 binds to c-Met via the Gabl adaptor protein. Interestingly, although binding of Dock7 to c-Met was not affected by Gab1 depletion, the HGF-induced increase in binding of Dock7 to c-Met was abolished in Gab1-depleted cells, indicating that this adaptor protein mediates the increased interaction between c-Met and Dock7 upon stimulation with HGF (Figure 6B and C). To further investigate this, we examined the presence of Gab1 in Dock7 immunoprecipitates and found that Dock7 indeed interacts with Gab1 and that this interaction is increased upon HGF stimulation (Figure 6D). As a control, we performed the same analysis in Dock7 knockdown cells and observed decreased Gab1 in the corresponding Dock7 immunoprecipitate (Figure 6E). Thus, taken together, these data indicate that Dock7 interacts with c-Met and that this interaction is mediated, at least in part, by Gabl. 
Gab1 adaptor protein is required for HGF-dependent GBM cell invasion, Rac1 activation and Dock7 activation. To further investigate the role of Gab1 as a mediator of c-Met in the control
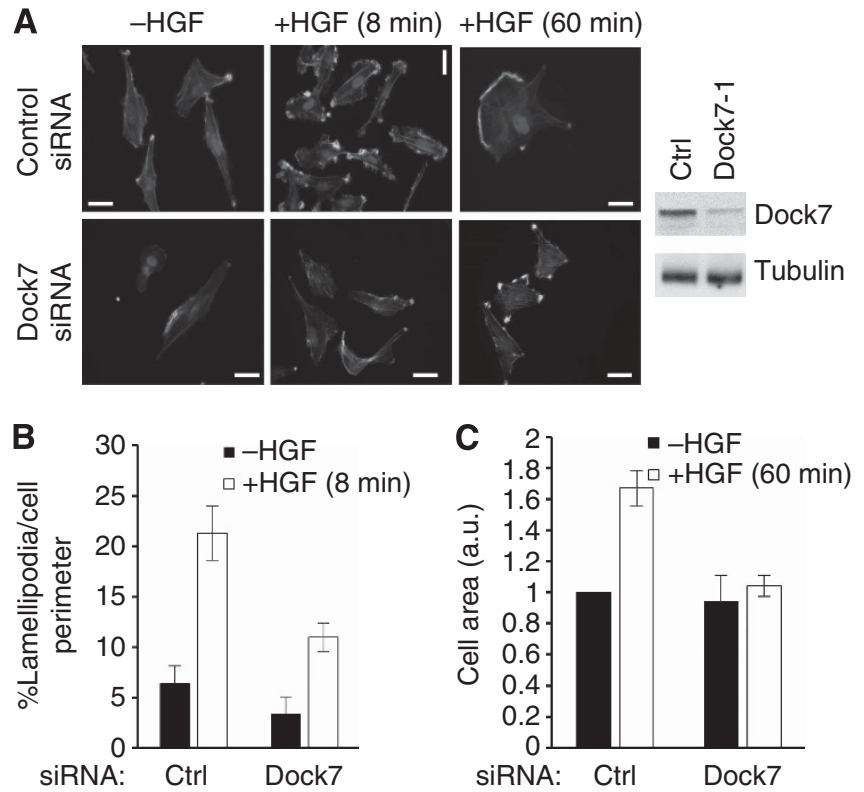

Figure 5. Dock7 is required for HGF-induced lamellipodia formation in SNB19 cells. (A) Micrographs of control and Dock7 knockdown cells (using the duplex Dock7-1) stimulated with HGF for 8 or $60 \mathrm{~min}$ and stained with fluorescently labelled phalloidin (right panel; confirmation of knockdown). (B) Quantification of lamellipodia formation.

(C) Quantification of cell area. Bars, $10 \mu \mathrm{m}$. of glioblastoma cell invasion, we examined the effect of Gab1 depletion on both HGF-induced invasion and Racl activation.

Depletion of Gab1 strongly inhibited HGF-induced U87R cell invasion (Figure 7A) and abolished HGF-induced Racl activation (Figure 7B). Interestingly, depletion of Gabl caused an increase in basal Rac1 activity, suggesting the existence of a compensatory mechanism that regulates Racl activation.

As Dock7 mediates HGF-stimulated glioblastoma cell invasion, we also investigated whether Dock7 is activated by HGF and whether Gab1 mediates this activation. Using the GST-Rac1-G15A nucleotide binding-deficient mutant to pull down active Dock7 out of cell lysates (Guilluy et al, 2011), we observed robust stimulation of Dock7 activity by HGF that is abolished by depletion of Gab1 (Figure $7 \mathrm{C}$ and $\mathrm{D}$ ). In addition, in line with our observation that depletion of Gabl causes an increase in basal Racl activity, we also observed that depleting Gab1 enhances Dock7 activation.

\section{DISCUSSION}

In this study, we showed that Dock7 expression levels are increased in glioblastoma $v s$ non-neoplastic brain. In addition, we identified an important role for Dock7 in the invasive behaviour of glioblastoma cells, by mediating HGF-induced Rac activation.

In a previous study, we have provided evidence that Racl is constitutively activated in a significant fraction of human GBM tumours (Salhia et al, 2008). Our observations add Dock7 to a growing list of GEFs, including Trio, Vav3, SWAP-70, Ect2, and SGEF that have been shown to be overexpressed in GBM tumours and promote Racl activation (Salhia et al, 2008; Seol et al, 2009; Fortin Ensign et al, 2013). Dock7, Trio, Vav3 and SWAP-70

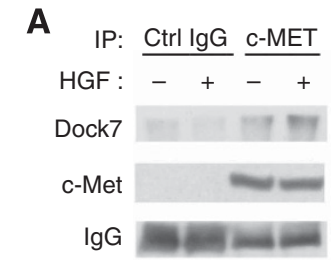

B

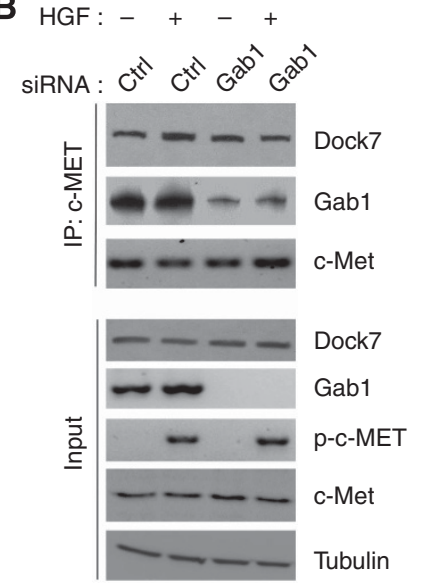

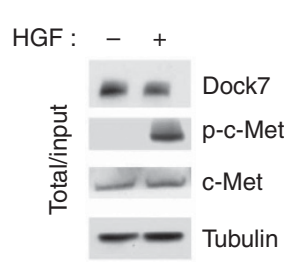

D<smiles>[C-]=C[SeH]</smiles>
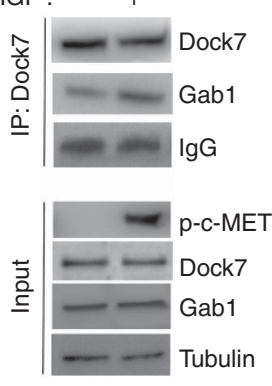
SiRNA : $0^{x i} 0^{0^{x}}$
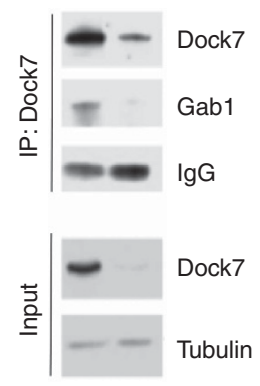

Figure 6. Dock7 binds activated c-Met in a Gab1-dependent manner. (A) Confirmation of c-Met immunoprecipitation specificity using a control rabbit IgG and subsequent immunoblot for Dock7 and c-Met. (B) Western blot demonstrating immunoprecipitation of Dock7 with c-Met from U87R cells. Experiments were performed 3 days after siRNA transfection. (C) Quantification of immunoprecipitation data from five independent experiments, exemplified in (B). Using the ImageJ software, densitometry values for immunoprecipitated Dock7 were normalised to the corresponding densitometry values for c-Met in the immunoprecipitate. (D) Western blot demonstrating immunoprecipitation of Dock7 with Gab1 from U87R cells. (E) Confirmation of Dock7 immunoprecipitation specificity using Dock7 siRNA to show specific pull down of Gab1 with Dock7. ${ }^{\star} P<0.05$, two-tailed t-test. 
A
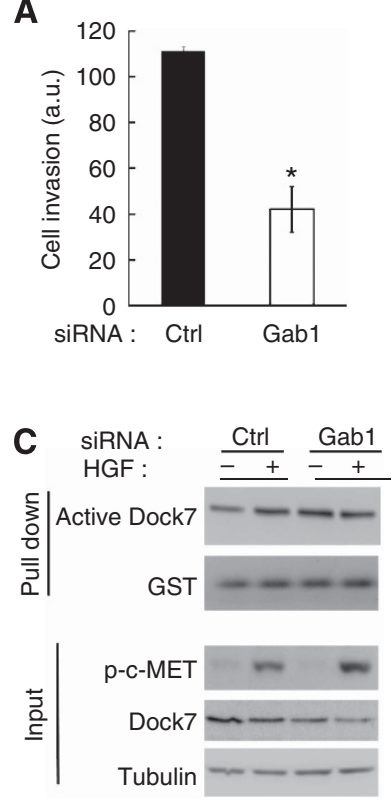
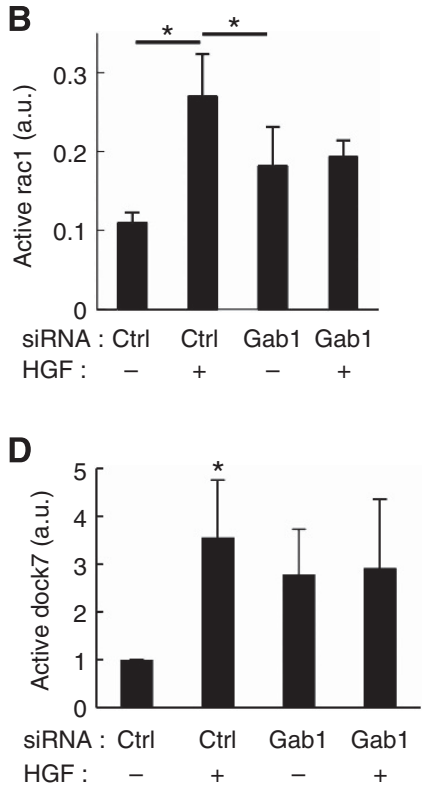

Figure 7. Gab1 mediates HGF-induced cell invasion and activation of Dock7 and Rac1. (A) Gab1 depletion reduces HGF-induced U87R cell invasion. Experiments were performed 3 days after siRNA transfection. (B) Gab1 depletion inhibits HGF-induced Rac1 activation measured by G-Lisa assay. Experiments were performed 3 days after siRNA transfection. (C) The role of Gab1 in HGF-induced Dock7 activation. Experiments were performed 3 days after transfection. Active Dock7 was pulled down using GST-Rac1-15A and subsequently measured by western blotting. (D) Quantification of Dock7 activation data from eight independent experiments, exemplified in (C). Activated Dock7 was normalised to the amount of GST-Rac1-15A in the pull down. ${ }^{\star} P<0.05$, two-tailed t-test.

can directly activate Rac1, whereas Ect2 and SGEF are likely to stimulate Racl activity via Cdc42 and RhoG, respectively. Thus, overexpression of these GEFs, in addition to downregulation of RacGAPs, such as $\beta 2$-chimaerin (Yuan et al, 1995), is likely to contribute to hyperactivation of Rac1 in GBM. Our observations that Dock7 mediates invasion-promoting signalling driven by $\mathrm{HGF} / \mathrm{c}-\mathrm{Met}$, a signalling axis that is hyperactive in GBM, add further clinical significance to our findings.

Interestingly, whereas Rac1 has been shown to be required for glioblastoma cell proliferation and survival (Senger et al, 2002; Chan et al, 2005; Kwiatkowska et al, 2012), we found that depletion of Dock7, only had a marginal, if any, inhibitory effect on these functions. These observations suggest that Dock7, in addition to its catalytic activity, also may direct Rac1-controlled signals towards downstream pathways that are responsible for regulating cell migration and invasion. Such selective activation of downstream signalling could occur via interaction of GEFs with scaffold proteins (Marinissen and Gutkind, 2005; García-Mata and Burridge, 2007).

Importantly, our molecular analysis showed that Dock7 interacts with c-Met in a manner that partially depends on the Gab1-adaptor protein. We found that Gab1 is necessary for HGFstimulated binding of Dock7 to c-Met, suggesting that Dock7 is recruited to the receptor complex upon binding of Gab1 to the activated receptor. We also found that Dock7 activity is increased by c-Met ligation. The mechanistic basis for this increase in Dock7 activity remains to be elucidated. One possibility is that c-Met phosphorylates Dock7, thereby enhancing its catalytic activity, as has been shown to be the case for ErbB2 (Yamauchi et al, 2008). Another possibility is that binding of Dock7 to Gabl leads to a

conformational change in Dock7, thereby activating it. Interestingly, in our study depletion of Gabl causes an increase in the activities of both Dock7 and Rac1, independently of HGF stimulation. This suggests the existence of a compensatory mechanism that modulates the Dock7-Racl axis in the absence of Gab1. Future efforts will be directed towards exploring the mechanistic basis of this compensatory mechanism, focusing on the possible roles of other c-Met adaptor proteins including Crk and Grb2.

We further showed that Dock7 is necessary for HGF-induced Rac1 activation. HGF has been shown to activate Rac1 in a number of different cell systems (Palamidessi et al, 2008; Abella et al, 2010). Interestingly, the Rac-specific GEF Tiam1 has been shown to mediate HGF-induced Rac activation in HeLa cells, whereas here we document a role for Dock7 in HGF-induced Rac activation in glioblastoma cells. Whether c-Met signalling is relayed by different Rho GEFs in different cell systems is an important question to be addressed in future studies.

There is mounting evidence that $\mathrm{HGF} / \mathrm{c}$-Met-controlled signalling elements constitute relevant targets for therapeutic intervention in the management of glioblastoma (Steffan et al, 2011; Gherardi et al, 2012; Rath et al, 2013), underscoring the importance of improving our understanding of c-Met activated signalling. In principle, GEFs represent good targets for the management of GBM as they convey high signalling specificity, thereby limiting off-target effects of GEF inhibitors (Vigil et al, 2010). Moreover, the small molecule GEF inhibitor space is continuing to expand and a number of inhibitors have been successfully developed (Bouquier et al, 2009; Evelyn et al, 2009; Ferri et al, 2009; Shang et al, 2013). Emerging technologies, such as tumour-targeted delivery of gene-specific siRNAs, may provide additional therapeutic avenues.

\section{ACKNOWLEDGEMENTS}

We wish to thank Dr Peter Gregersen for establishing the Feinstein Institute Brain Tumor Tissue Donation Program; Dr Alexis Demopoulos and Mary Keogh for designing and implementing the IRB protocol. This work was funded by the Health Research Board (Ireland) (to DWM), the European Commission 7th Framework Programme (Ref\#MCPD/2010/7 to DWM), NINDS R21 NS060023 (MS), NCI R01 CA130940 (NLT), R01 MH082808 (LVA) and grants from Project To Cure (MS) and The Feinstein Institute (MS).

\section{REFERENCES}

Abella JV, Vaillancourt R, Frigault MM, Ponzo MG, Zuo D, Sangwan V, Larose L, Park M (2010) The Gab1 scaffold regulates RTK-dependent dorsal ruffle formation through the adaptor Nck. J Cell Sci 123(Pt 8): 1306-1319.

Abounader R, Ranganathan S, Lal B, Fielding K, Book A, Dietz H, Burger P, Laterra J (1999) Reversion of human glioblastoma malignancy by U1 small nuclear RNA/ribozyme targeting of scatter factor/hepatocyte growth factor and c-met expression. J Natl Cancer Inst 91: 1548-1556.

Azim AC, Barkalow KL, Hartwig JH (2000) Determination of GTP loading on Rac and Cdc42 in platelets and fibroblasts. Methods Enzymol 325: 257-263.

Beckner ME, Chen X, An J, Day BW, Pollack IF (2005) Proteomic characterization of harvested pseudopodia with differential gel electrophoresis and specific antibodies. Lab Invest 85: 316-327.

Birchmeier C, Birchmeier W, Gherardi E, Vande Woude GF (2003) Met, metastasis, motility and more. Nat Rev Mol Cell Biol 4(12): 915-925.

Bosse T, Ehinger J, Czuchra A, Benesch S, Steffen A, Wu X, Schloen K, Niemann HH, Scita G, Stradal TE, Brakebusch C, Rottner K (2007) Cdc42 and phosphoinositide 3-kinase drive Rac-mediated actin polymerization downstream of c-Met in distinct and common pathways. J Mol Cell Biol 27(19): 6615-6628. 
Bouquier N, Vignal E, Charrasse S, Weill M, Schmidt S, Léonetti JP, Blangy A, Fort P (2009) A cell active chemical GEF inhibitor selectively targets the Trio/RhoG/Racl signaling pathway. Chem Biol 16: 657-666.

Brockmann MA, Ulbricht U, Gruner K, Fillbrandt R, Westphal M, Lamszus K (2003) Glioblastoma and cerebral microvascular endothelial cell migration in response to tumor-associated growth factors. Neurosurgery 52: 1391-1399.

Burridge K, Wennerberg K (2004) Rho and Rac take center stage. Cell 116(2): 167-179.

Bustelo XR, Sauzeau V, Berenjeno IM (2007) GTP-binding proteins of the Rho/Rac family: regulation, effectors and functions in vivo. Bioessays 29(4): 356-370.

Chan AY, Coniglio SJ, Chuang YY, Michaelson D, Knaus UG, Philips MR, Symons M (2005) Roles of the Rac1 and Rac3 GTPases in human tumor cell invasion. Oncogene 24(53): 7821-7829.

Chaudhuri A, Xie MH, Yang B, Mahapatra K, Liu J, Marsters S, Bodepudi S, Ashkenazi A (2011) Distinct involvement of the Gab1 and Grb2 adaptor proteins in signal transduction by the related receptor tyrosine kinases RON and MET. J Biol Chem 286: 32762-32774.

Dugina VB, Alexandrova AY, Lane K, Bulanova E, Vasiliev JM (1995) The role of the microtubular system in the cell response to HGF/SF. J Cell Sci 108: $1659-1667$.

Evelyn CR, Ferng T, Rojas RJ, Larsen MJ, Sondek J, Neubig RR (2009) High-throughput screening for small-molecule inhibitors of LARGstimulated RhoA nucleotide binding via a novel fluorescence polarization assay. J Biomol Screen 14: 161-172.

Ferri N, Corsini A, Bottino P, Clerici F, Contini A (2009) Virtual screening approach for the identification of new Rac1 inhibitors. J Med Chem 52: 4087-4090.

Fortin Ensign SP, Mathews IT, Eschbacher JM, Loftus JC, Symons MH, Tran NL (2013) SGEF is overexpressed in high grade gliomas and promotes TWEAK-Fn14-induced cell migration and invasion via TRAF2. J Biol Chem 288: 21887-21897.

Fortin SP, Ennis MJ, Schumacher CA, Zylstra-Diegel CR, Williams BO, Ross JT, Winkles JA, Loftus JC, Symons MH, Tran NL (2012) Cdc42 and the guanine nucleotide exchange factors Ect2 and trio mediate Fn14-induced migration and invasion of glioblastoma cells. Mol Cancer Res 10: 958-968.

Furnari FB, Fenton T, Bachoo RM, Mukasa A, Stommel JM, Stegh A, Hahn WC, Ligon KL, Louis DN, Brennan C, Chin L, DePinho RA, Cavenee WK (2007) Malignant astrocytic glioma: genetics, biology, and paths to treatment. Genes Dev 21: 2683-2710.

García-Mata R, Burridge K (2007) Catching a GEF by its tail. Trends Cell Biol 17(1): $36-43$

Gherardi E, Birchmeier W, Birchmeier C, Vande Woude G (2012) Targeting MET in cancer: rationale and progress. Nat Rev Cancer 12(2): 89-103.

Guilluy C, Dubash AD, Garcia-Mata R (2011) Analysis of RhoA and Rho GEF activity in whole cells and the cell nucleus. Nat Protoc 6: 2050-2060.

Heasman SJ, Ridley AJ (2008) Mammalian Rho GTPases: new insights into their functions from in vivo studies. Nat Rev Mol Cell Biol 9: 690-701.

Johnston AL, Lun X, Rahn JJ, Liacini A, Wang L, Hamilton MG, Parney IF, Hempstead BL, Robbins SM, Forsyth PA, Senger DL (2007) The p75 neurotrophin receptor is a central regulator of glioma invasion. PLoS Biol 5: e212.

Keunen O, Johansson M, Oudin A, Sanzey M, Rahim SA, Fack F, Thorsen F, Taxt T, Bartos M, Jirik R, Miletic H, Wang J, Stieber D, Stuhr L, Moen I, Rygh CB, Bjerkvig R, Niclou SP (2011) Anti-VEGF treatment reduces blood supply and increases tumor cell invasion in glioblastoma. Proc Natl Acad Sci USA 108: 3749-3754.

Kohler BA, Ward E, McCarthy BJ, Schymura MJ, Ries LA, Eheman C, Jemal A, Anderson RN, Ajani UA, Edwards BK (2011) Annual report to the nation on the status of cancer, 1975-2007, featuring tumors of the brain and other nervous system. J Natl Cancer Inst 103: 714-736.

Koochekpour S, Jeffers M, Rulong S, Taylor G, Klineberg E, Hudson EA, Resau JH, Vande Woude GF (1997) Met and hepatocyte growth factor/ scatter factor expression in human gliomas. Cancer Res 57: 5391-5398.

Kozma R, Ahmed S, Best A, Lim L (1995) The Ras-related protein Cdc42Hs and bradykinin promote formation of peripheral actin microspikes and filopodia in Swiss 3T3 fibroblasts. Mol Cell Biol 15(4): 1942-1952.

Kwiatkowska A, Didier S, Fortin S, Chuang Y, White T, Berens ME, Rushing E, Eschbacher J, Tran NL, Chan A, Symons M (2012) The small GTPase RhoG mediates glioblastoma cell invasion. Mol Cancer 11: 65 .

Kwiatkowska A, Symons M (2013) Signaling determinants of glioma cell invasion. Adv Exp Med Biol 986: 121-141.
Lamszus K, Laterra J, Westphal M, Rosen EM (1999) Scatter factor/hepatocyte growth factor (SF/HGF) content and function in human gliomas. Int $J$ Dev Neurosci 17: 517-530.

Lu KV, Chang JP, Parachoniak CA, Pandika MM, Aghi MK, Meyronet D, Isachenko N, Fouse SD, Phillips JJ, Cheresh DA, Park M, Bergers G (2012) VEGF inhibits tumor cell invasion and mesenchymal transition through a MET/VEGFR2 complex. Cancer Cell 22: 21-35.

Lucio-Eterovic AK, Piao Y, de Groot JF (2009) Mediators of glioblastoma resistance and invasion during antivascular endothelial growth factor therapy. Clin Cancer Res 15: 4589-4599.

Marinissen MJ, Gutkind JS (2005) Scaffold proteins dictate Rho GTPase-signaling specificity. Trends Biochem Sci 30: 423-426.

Matsumoto K, Matsumoto K, Nakamura T, Kramer RH (1994) Hepatocyte growth factor/scatter factor induces tyrosine phosphorylation of focal adhesion kinase (p125FAK) and promotes migration and invasion by oral squamous cell carcinoma cells. J Biol Chem 269(50): 31807-31813.

Palamidessi A, Frittoli E, Garré M, Faretta M, Mione M, Testa I, Diaspro A, Lanzetti L, Scita G, Di Fiore PP (2008) Endocytic trafficking of Rac is required for the spatial restriction of signaling in cell migration. Cell 134(1): 135-147.

Rath P, Lal B, Ajala O, Li Y, Xia S, Kim J, Laterra J (2013) In vivo c-Met pathway inhibition depletes human glioma xenografts of tumorpropagating stem-like cells. Transl Oncol 6(2): 104-111.

Ricard D, Idbaih A, Ducray F, Lahutte M, Hoang-Xuan K, Delattre JY (2012) Primary brain tumours in adults. Lancet 379: 1984-1996.

Ridley AJ, Paterson HF, Johnston CL, Diekmann D, Hall A (1992) The small GTP-binding protein Rac regulates growth factor induced membrane ruffling. Cell 70: 401-410.

Rosen EM, Laterra J, Joseph A, Jin L, Fuchs A, Way D, Witte M, Weinand M, Goldberg ID (1996) Scatter factor expression and regulation in human glial tumors. Int J Cancer 67: 248-255.

Royal I, Lamarche-Vane N, Lamorte L, Kaibuchi K, Park M (2000) Activation of cdc42, rac, PAK, and rho-kinase in response to hepatocyte growth factor differentially regulates epithelial cell colony spreading and dissociation. Mol Biol Cell 11(5): 1709-1725.

Sahai E, Marshall CJ (2002) RHO-GTPases and cancer. Nat Rev Cancer 2: $133-142$.

Salhia B, Tran NL, Chan A, Wolf A, Nakada M, Rutka F, Ennis M, McDonough WS, Berens ME, Symons M, Rutka JT (2008) The guanine nucleotide exchange factors trio, Ect2, and Vav3 mediate the invasive behavior of glioblastoma. Am J Pathol 173: 1828-1838.

Schmidt A, Hall A (2002) Guanine nucleotide exchange factors for Rho GTPases: turning on the switch. Genes Dev 16(13): 1587-1609.

Senger DL, Tudan C, Guiot MC, Mazzoni IE, Molenkamp G, LeBlanc R, Antel J, Olivier A, Snipes GJ, Kaplan DR (2002) Suppression of Rac activity induces apoptosis of human glioma cells but not normal human astrocytes. Cancer Res 62(7): 2131-2140.

Seol HJ, Smith CA, Salhia B, Rutka JT (2009) The guanine nucleotide exchange factor SWAP-70 modulates the migration and invasiveness of human malignant glioma cells. Transl Oncol 2(4): 300-309.

Shang X, Marchioni F, Evelyn CR, Sipes N, Zhou X, Seibel W, Wortman M, Zheng Y (2013) Small-molecule inhibitors targeting G-protein-coupled Rho guanine nucleotide exchange factors. Proc Natl Acad Sci USA 110(8): 3155-3160.

Steffan JJ, Coleman DT, Cardelli JA (2011) The HGF-met signaling axis: emerging themes and targets of inhibition. Curr Protein Pept Sci 12(1): $12-22$.

Tran NL, McDonough WS, Savitch BA, Fortin SP, Winkles JA, Symons M, Nakada M, Cunliffe HE, Hostetter G, Hoelzinger DB, Rennert JL, Michaelson JS, Burkly LC, Lipinski CA, Loftus JC, Mariani L, Berens ME (2006) Increased fibroblast growth factor-inducible 14 expression levels promote glioma cell invasion via Rac1 and nuclear factor-kappaB and correlate with poor patient outcome. Cancer Res 66: 9535-9542.

Valster A, Tran NL, Nakada M, Berens ME, Chan AY, Symons M (2005) Cell migration and invasion assays. Methods 37: 208-215.

van der Meel R, Symons MH, Kudernatsch R, Kok RJ, Schiffelers RM, Storm G, Gallagher WM, Byrne AT (2011) The VEGF/Rho GTPase signalling pathway: a promising target for anti-angiogenic/anti-invasion therapy. Drug Discov Today 16(5-6): 219-228.

Van Meir EG, Hadjipanayis CG, Norden AD, Shu HK, Wen PY, Olson JJ (2010) Exciting new advances in neuro-oncology: the avenue to a cure for malignant glioma. CA Cancer J Clin 60: 166-193. 
Vigil D, Cherfils J, Rossman KL, Der CJ (2010) Ras superfamily GEFs and GAPs: validated and tractable targets for cancer therapy? Nat Rev Cancer 10(12): 842-857.

Watabe-Uchida M, John KA, Janas JA, Newey SE, Van Aelst L (2006) The Rac activator DOCK7 regulates neuronal polarity through local phosphorylation of stathmin/Op18. Neuron 51: 727-739.

Watanabe T, Tsuda M, Makino Y, Ichihara S, Sawa H, Minami A, Mochizuki N, Nagashima K, Tanaka S (2006) Adaptor molecule Crk is required for sustained phosphorylation of Grb2-associated binder 1 and hepatocyte growth factor-induced cell motility of human synovial sarcoma cell lines. Mol Cancer Res 4: 499-510.

Yamauchi J, Miyamoto Y, Chan JR, Tanoue A (2008) ErbB2 directly activates the exchange factor Dock7 to promote Schwann cell migration. J Cell Biol 181: $351-365$
Yuan S, Miller DW, Barnett GH, Hahn JF, Williams BR (1995) Identification and characterization of human beta 2-chimaerin: association with malignant transformation in astrocytoma. Cancer Res 55(15): 3456-3461.

Zhou Y, Johnson JL, Cerione RA, Erickson JW (2013) Prenylation and membrane localization of Cdc42 are essential for activation by DOCK7. Biochemistry 52(25): 4354-4363.

This work is published under the standard license to publish agreement. After 12 months the work will become freely available and the license terms will switch to a Creative Commons AttributionNonCommercial-Share Alike 3.0 Unported License. 